\title{
The use of audio visual promotion media towards the improvement of teenagers' knowledge and attitude about HIV/AIDS
}

\author{
Eny Retna Ambarwati ${ }^{1}$, Isabella Rahmawati ${ }^{2}$, Triyani Mawarti ${ }^{3}$ \\ ${ }^{1,2}$ Study Program of Diploma III in Midwifery, Institute of Health Science Akbidyo, Yogyakarta, Indonesia \\ ${ }^{3}$ Faculty of Public Health, Universitas Ahmad Dahlan, Yogyakarta, Indonesia
}

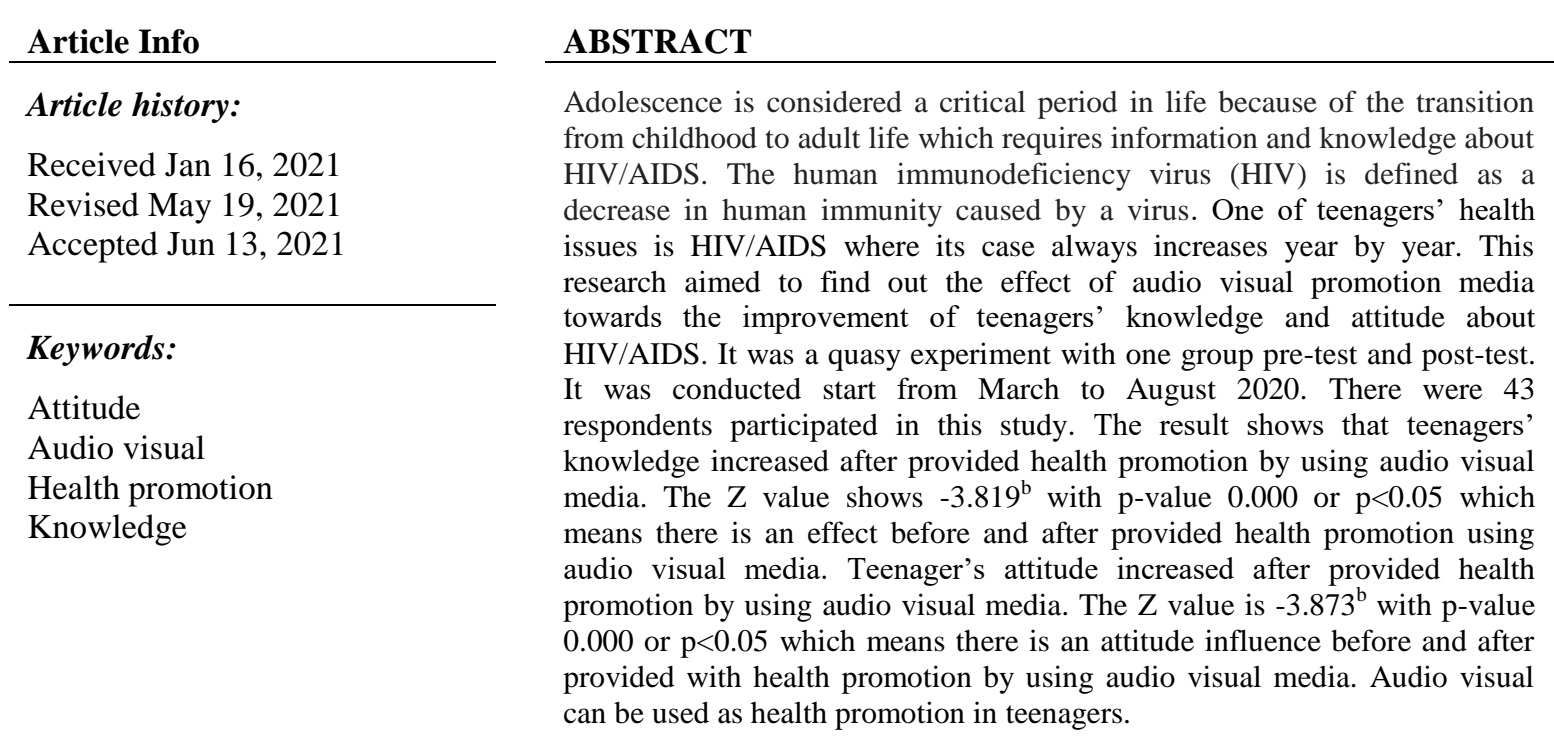

This is an open access article under the CC BY-SA license.

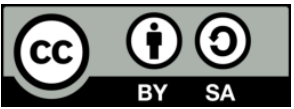

\section{Corresponding Author:}

Eny Retna Ambarwati

Study Program of Diploma III in Midwifery

Institute of Health Science Akbidyo

Yogyakarta, Indonesia

Email: enyretna@gmail.com

\section{INTRODUCTION}

Adolescence is considered as the critical period in this life because it is a transition era from childhood to adult life. In the adolescence era, there is a shift occurred both physically and emotionally. It can cause teenagers become susceptible towards risky behavior problems in the transmission of acquired immunodeficiency syndrome (HIV/AIDS). HIV/AIDS has already been the health issue in the world since 1981. HIV/AIDS case is iceberg phenomenon where the reported people are less than the real cases that grows year by year. Both the medicine and the vaccine to encounter HIV/AIDS have not discovered yet, so it can damage the immune system that can cause the decline of immune system and losses in the social, economical, politics, culture, and demographics field [1].

Based on the data from Directorate General of Disease Control and Environmental Health [2], HIV and AIDS cases show a cumulative number reaching to half million or 500,000 that is 466,589 consisting of 349,882 HIV and 116,977 AIDS. The estimation of HIV/AIDS cases in 2016 shows 640,443. It means that 
only $60.70 \%$ cases detected and there are 290,561 citizens who suffer HIV/AIDS but undetected. From epidemiology aspect, those people are link of HIV/AIDS spread in the society by having sexual course without condoms in and out of marriage.

HIV/AIDS cases in teenagers cannot be separated from the globalization era. The globalization era causes social shift and life style in teenagers that can cause HIV/AIDS transmission. Some teenagers do not have the correct knowledge about HIV/AIDS. They usually get information from friend, electronic media, or printed media where the information sometimes less accurate or inaccurate. The incorrect information can plunge teenagers to promiscuity that can lead to the transmission of HIV/AIDS. One way to prevent HIV/AID transmission is by health promotion.

Health promotion in the sense of education is all planned efforts to influence others, individually, groups, or society so they do like what educators expect or health promotion [3]. Health promotion is needed to improve knowledge and teenagers awareness to prevent HIV/AIDS since there is no medication or vaccine that can prevent HIV/AIDS spread [4]. Health promotion does not only revive or improve knowledge about health but also efforts to facilitate that aim to change the behavior [5]. The success of health promotion is influenced by many factors, one of them is media. Media of health promotion is one of the components in the learning process. The interesting media will give faith, so the change in cognitive, affective, and psychomotor can be fasten.

Along with the rapid development of the times, making the world of technology become more modern so that various media that can support health promotion have emerged. One of the media that has experienced development is audio visual media [6]. Audio-visual media encourages the desire to know more [7]. Audio visual media uses more senses that can encourage the receiver to use the sense of hearing and sense of sight so the information can be received well. This is in accordance with the theory put forward by Suiraoka and Supariasa [8] which states that a person will remember $20 \%$ of what was heard, remember $50 \%$ of what was seen and remember $80 \%$ of what was heard, seen and immediately done. Furthermore, audiovisual media can stimulate the motion effects so it looks more interesting, easier to stimulate understanding, enriches and provides a concrete experience [9]. Research conducted by Kapti et al. [10] shows that there are differences in knowledge and attitudes after being given health education with audio-visual media. The teenagers' knowledge will influence their attitude about the situation in the environment around them. The knowledge of HIV/AIDS in various studies shows that this is the most dominant factor in determining attitudes towards the occurrence of HIV/AIDS [11].

\section{RESEARCH METHOD}

This research employed quasi experimental design with a pre-post test design in one group (one group pre-post test design) [12]. The treatment given was health promotion using audio-visual media about HIV/AIDS and measurement (O1 and $\mathrm{O} 2)$ was the teenagers' knowledge and attitudes about HIV/AIDS. There were 43 respondents involved in this study. The sample technique used in this study was accidental sampling. The instrument used in this study was a questionnaire sheet to determine knowledge and attitudes about HIV/AIDS. The data processing procedure carried out through the editing, coding, scoring and tabulating stages and the data were analyzed through univariate and bivariate analysis procedures using the Wilcoxon test at a significance level of $95 \%(\alpha=0.05)$.

\section{RESULTS AND DISCUSSION}

\subsection{The characteristics of respondents}

Table 1 shows that from 43 research respondents, there were 22 respondents $(51.2 \%)$ aged $\geq 18$ years old. There was one respondent at the age of 19 years old, including the late teenager category. At this time, teenagers have the physical development of the body to reach adulthood, have a unique identity, opinions and ideas that can be resolved [13]. Parents' education is defined as the parents' highest formal education which have ever been attended and proven by a certificate. The statistical data shows that there were 18 respondents (41.9\%) where most of the respondents' parents have an education level of SMA/K. It shows that most of the respondents' parents have completed senior secondary education. Education improves communication with other family members, moreover education instills self-worth and self-confidence which are very important in realizing health-related behavior change [14].

Parents' work is defined as parent's daily activities or activities for a living. The statistical data shows that there are 20 respondents $(46.5 \%)$ or parents who work as self-employed and one respondent $(2.3 \%)$ a small proportion of parents work as village heads, village officials, merchants or security. Based on health information sources, it was found that there were 35 respondents $(81.4 \%)$ obtained information sources from various media and eight respondents (18.6\%) did not get information sources. The rapid 
dissemination of information is an opportunity to increase knowledge as well as a challenge to get the right information [15]. The easiness of obtaining information has both positive and negative impacts on teenagers. The positive impact is that knowledge can be easily obtained [16]. The more often a person has more sources of information, the more extensive the knowledge will be.

Table 1. The description of respondents characteristics based on age, parents' educational background,

\begin{tabular}{|c|c|c|c|}
\hline No. & Respodents' characteristics & Frequency & Percentage \\
\hline \multirow[t]{5}{*}{1.} & Age & & \\
\hline & a. $\geq 18$ year & 22 & 51.2 \\
\hline & b. $\geq 19$ year & 13 & 30.2 \\
\hline & $\geq 20$ year & 7 & 16.3 \\
\hline & d. $\quad \geq 21$ year & 1 & 2.3 \\
\hline \multirow[t]{7}{*}{2.} & Parents' educational background & & \\
\hline & a. $\quad$ Primary School & 7 & 16.3 \\
\hline & b. Secondary School & 3 & 7.0 \\
\hline & c. Senior high School & 18 & 41.9 \\
\hline & d. Associate Degree & 6 & 14.0 \\
\hline & Bachelor degree & 2 & 4.7 \\
\hline & f. Master Degree & 7 & 16.3 \\
\hline \multirow[t]{11}{*}{3.} & Parents'occupation & & \\
\hline & a. Labor & 3 & 7.0 \\
\hline & b. Teacher & 2 & 4.7 \\
\hline & c. Private employee & 4 & 9.3 \\
\hline & Village head & 1 & 2.3 \\
\hline & e. Merchant & 1 & 2.3 \\
\hline & Village official & 1 & 2.3 \\
\hline & Farmer & 3 & 7.0 \\
\hline & Civil servant & 7 & 16.3 \\
\hline & i. $\quad$ Security & 1 & 2.3 \\
\hline & j. $\quad$ Entrepreneur & 20 & 46.5 \\
\hline \multirow[t]{4}{*}{4} & Source of health information & & \\
\hline & a. Unavailable & 8 & 18.6 \\
\hline & b. Available & 35 & 81.4 \\
\hline & & 43 & 100.00 \\
\hline
\end{tabular}

\subsection{The frequency distribution of teenager's attitude and knowledge before and after intervention with audio visual media}

Based on Table 2, the teenagers knowledge about HIV/AIDS before given health promotion using audio visual media, there were 43 teenagers $(100 \%)$ who had less knowledge about HIV AIDS, whereas after given health promotion using audiovisual media there were two people $(4.7 \%)$ who had better result. There were 14 people $(32.6 \%)$ who had fair knowledge and there were 27 people $(62.8 \%)$ who had less knowledge. It shows that after being given health promotion using audiovisual media, the respondents had improved their knowledge about HIV/AIDS. There are six levels of knowledge in the cognitive domain, including: knowing, understanding, application, analysis, synthesis, evaluation [17]. Knowledge is the result of knowing, and it happens after someone senses a certain object. Sensing occurs through the five human senses, namely the senses of sight, hearing, smell, taste, and touch [18].

Table 2. Teenagers' knowledge before and after intervention with audio visual media

\begin{tabular}{ccccc}
\hline Teenagers' knowledge & \multicolumn{3}{c}{ Pretest } & Postest \\
& Frequency (f) & Percentage (\%) & Frequency (f) & Percentage (\%) \\
\hline Good & 0 & 00.00 & 2 & 4.7 \\
Fair & 0 & 00.00 & 14 & 32.6 \\
Less & 43 & 100.00 & 27 & 62.8 \\
Total & 43 & 100.00 & 43 & 100.00 \\
\hline Source: Primary data, 2020 & &
\end{tabular}

\subsection{The frequency distribution of teenager's attitude before and after intervention with audio visual media}

Based on Table 3 of teenagers' attitude about HIV/AIDS before given health promotion using audiovisual media, there were 42 people $(97.70 \%)$ had poor attitudes, whereas after given health promotion using audiovisual media, there was one person $(2.3 \%)$ who showed good result. There were 14 people 
$(32.60 \%)$ who had a fair enough attitude and there were 28 people $(65.10 \%)$ who had poor attitude. It shows that the respondents had improved their attitude about HIV/AIDS after being given health promotion using audiovisual media. Attitude is a collection of symptoms or syndromes in response to a stimulus or object, thus involving thoughts, feelings, attention, and other psychological symptoms [19]. Attitudes can change depend on the environmental conditions around the individual at different times and places which are stated in the three ABC domains, namely affect is a feeling that arises (happy, displeased), behavior is behavior that follows that feeling (approaching, avoidance) and cognition is an assessment of the attitude object (good, not good).

Table 3. Teenagers' attitude and knowledge before and after intervention with audio visual media

\begin{tabular}{ccccc}
\hline \multirow{2}{*}{ Teenagers' attitude } & \multicolumn{2}{c}{ Pretest } & \multicolumn{2}{c}{ Postest } \\
& Frequency(f) & Percentage (\%) & Frequency (f) & Percentage (\%) \\
\hline Good & 0 & 00.00 & 1 & 2.3 \\
Fair enough & 1 & 2.3 & 14 & 32.6 \\
Foor & 42 & 97.7 & 28 & 65.1 \\
Total & 43 & 100.00 & 43 & 100.00 \\
\hline Source: Primary data, 2020 & & & &
\end{tabular}

Source: Primary data, 2020

\subsection{The influence of knowledge and attitude before and after intervention with audio visual media}

Based on Table 4 the influence of knowledge and attitude before and after intervention with audio visual mediabelow shows that the average knowledge of adolescents before and after being given health promotion using audio-visual media was 16, then increased to 27 after given health promotion.

Table 4. Knowledge and attitude before and after intervention with audio visual media

\begin{tabular}{cccc}
\hline Mean & Pre test & Post test & $\mathrm{p}$ \\
\hline Teenagers' knowledge & 16 & 27 & 0.00 \\
Teenagers' attitude & 15 & 28 & \\
Total & 43 & 43 & \\
\hline
\end{tabular}

Source: Primary data, 2020

From the Wilcoxon Signed Rank Test results, it shows that $\mathrm{Z}$ value of $-3.819 \mathrm{~b}$ with p-value of 0.000 or $\mathrm{p}<0.05$ means that there is an influence of knowledge before and after given health promotion using audiovisual media. The attitude of teenagers before and after being given health promotion using audio-visual media was 15 , then increased to 28 after given health promotion. The $\mathrm{Z}$ value is $-3,873 \mathrm{~b}$ with a $\mathrm{p}$-value of 0.000 or $\mathrm{p}<0.05$, it means that there is an influence on attitude before and after being given health promotion using audio-visual media.

From the research results, it was found that all teenagers who got health promotion using audiovisual media experienced improvement in knowledge about HIV/AIDS. It could be caused by the use of media and interesting ways of conveying information that can improve youth enthusiasm to know HIV/AIDS. Coaching through health promotion and using audiovisual media can improve knowledge so that it can respond to attitudes leading to better behavior. A health promotion process to achieve the goals is influenced by many factors, including method factors, material factors or messages, educational goals, educators or health promotion officers, and the use of educational aids/props [20]. In this study, the presented materials interesting, seen from the respondents' enthusiasm, the educational target is students who are a very sensitive group to accept the change, so that they are easily guided, directed and instilled in good habits. However the media used in this health promotion is audiovisual media where researchers try to maximize the use of the five senses, both sight and hearing. The selection of health media as a means of health promotion is one of the keys to the success of achieving the information conveyed [21].

Audiovisuals make a very big contribution in the knowledge and attitude changes. There are two elements of audiovisual media, each of which has strength that synergizes into great strength. This media provides a stimulus to hearing and sight, so that the results obtained are maximized. It can be achieved because the senses that transmit the most knowledge to the brain are the eyes (approximately $75 \%$ to $87 \%$ ); while $13 \%$ to $25 \%$ of knowledge is obtained or transmitted through other senses [22]. The effectiveness of audio visual media is suitable with the research results conducted by Hapitria and Padmawati [23] that health education using audiovisual media is effective in improving knowledge. Research conducted by Nugroho [24] stated that the effect of health education using audio visuals in improving motivation to stop HIV/AIDS was more significant because it attracted someone's attention so that it aroused one's enthusiasm for 
information and was also easier to accept than using printed media. It is in line with Arsyad [25] opinion, learning process using multiple senses (audio and visual), namely the senses of hearing and sight, will provide benefits because teenagers will learn more if the lesson is presented with visual or hearing stimuli only.

Knowledge is influenced by many factors, including information or media. Information obtained from both formal and non-formal education can have an immediate impact, resulting in changes or knowledge improvement [26]. The existence of repeated information can improve one's belief that comes from one's own experiences or the others' experiences will improve one's attitude. In accordance with the theory put forward by Azwar [27] the factors that influence attitudes towards attitude objects include: personal experience, influence of other people who are considered important, cultural influence, mass media, educational institutions and religious institutions, emotional factors [28].

Attitude is a person's closed response towards a certain stimulus or object, which already involves the one's opinion and emotional factors (happy-displeased, agree-disagree, good-bad, and so on). Attitude is also a readiness or willingness to act, and is not an implementation of a particular motive. In other words, the function of attitude is not yet an action (open reaction) or activity, but rather a predisposition to behavior (action) or a closed reaction [20]. Attitude is a tendency that comes from within the individual to behave with certain patterns, towards an object due to the object's position and feeling. A complete attitude to a person can be formed if there are beliefs, ideas and concepts about an object, emotional life or emotional evaluation of an object and a tendency to act. Attitudes involve beliefs, feelings and thoughts that influence individuals in providing value to something they are interested in or vice versa [29]. Social cognitive theory states that attitudes are influenced by environmental factors, both physical and social. The physical environment of the informant's opinion includes the form of services, service places that are easily accessible and costs. The social environment that influences attitudes is support, friends, and community leaders [30].

Knowledge is one of the factors that influence a person's attitude and behavior. According to Lawrence Green and Marshall Kreuter, a person's knowledge is one of the predisposing factors that can influence changes in a person's behavior [28]. Actions based on knowledge are more durable than actions that are not conscious of knowledge. Green's theory in Notoatmodjo [31] states that knowledge is one of the predisposing factors in the formation of behavior. In addition, according to Jung et al. [32] health education about HIV/AIDS has a significant influence on attitudes about HIV/AIDS prevention. Providing health education about HIV/AIDS to adolescents is very important, because with health education to students, it can increase knowledge, change attitudes and apply it in daily life so that the goals of health education are achieved, namely increasing the degree of health (welfare), reducing dependence and provide opportunities for individuals, families, groups and communities to actualize themselves in maintaining optimal health Nursalam et al. [33]. This is in line with research conducted by Husaini et al. [34], where health education about HIV/AIDS has a significant effect on attitudes towards the incidence of HIV/AIDS [35]. Health education can affect a person's attitude in behaving healthy.

\section{CONCLUSION}

Giving health promotion through audiovisual media about HIV/AIDS can improve teenagers' knowledge and attitude about HIV/AIDS. Thus, giving health promotion about HIV/AIDS by using double senses (both audio and visual), namely hearing sense and sight sense can provide benefit because teenagers will learn more comparing to the lessons which is delivered in one point of view or hearing only.

\section{REFERENCES}

[1] Ardhiyanti, The basic concept of HIV/AIDS. In: Aids Teaching Materials in Midwifery Care, First. Yogyakarta: Deepublish, 2015.

[2] Directorate General of Disease Control and Environmental Health, "Report on the Situation of HIV/AIDS in Indonesia in 2019," Ministry of Health of the Republic of Indonesia, 2019.

[3] S. Notoatmodjo, Health Promotion and Health Behavior. Jakarta: Rineka Cipta, 2012

[4] Abdeyaz, Health promotion theory and application. Jakarta: Rineka Cipta, 2013.

[5] Soekidjo Notoatmodjo, Health Behavioral Science. Jakarta: Rineka Cipta, 2014.

[6] A. Febliza, Basic Statistics of Educational Research. Pekanbaru: Adefa Grafika, 2015.

[7] F. Firdaus, "Effectiveness of the Use of Audio-Visual Media in Learning Science," SPEKTRA J. Kaji. Pendidik. Sains, vol. 2, no. 1, pp. 46-54, 2016, doi: 10.32699/spektra.v2i01.6.

[8] P. and D. N. S. Suiraoka, Health Education Media. Yogyakarta: Graha Ilmu, 2012.

[9] Armah, "The Effect of Audio Visual Media on the Ability to Write News Texts," Lang. J., vol. 2, no. 2, 2013, doi: 10.24114 / kjb.v1i2.956.

[10] K. R. Eko, "The effectiveness of audiovisual as a medium for health education to increase knowledge and attitudes of mothers in the management of toddlers with diarrhea in two Malang city hospitals," Nursing (Lond)., vol. 1, no. $1,2013$. 
[11] M. B. Mutombo N., "Factors Influencing Attitudes towards People Living with HIV/AIDS in Zambia: Does HIV Testing Matter?," J Infect Dis Ther, vol. 3, no. 197, 2015, doi: 10.4172/2332-0877.1000197.

[12] Kelana, Nursing Research Methodology. Jakarta: Trans Info Media, 2011.

[13] Hurlock Elizabeth, Developmental Psychology: A Lifespan Approach. Jakarta: Erlangga, 2004.

[14] P. K. Singh, R. K. Rai, M. Alagarajan, and L. Singh, "Determinants of maternity care services utilization among married adolescents in rural India," PLoS One, vol. 7, no. 2, pp. 1-14, 2012, doi: 10.1371/journal.pone.0031666.

[15] Y. A. Mochamad Iqbal Nurmansyah and B. Al-Aufa, "Role of Family, Society and Media as a Source of Information on Reproductive Health Amongst University Students," J. Kesehat. Reproduksi, vol. 3, no. 1, pp. 1621, 2013, doi: 10.22435/jkr.v3i1Apr.3926.16-23.

[16] Y. D. and B. Rafael, "Socio Economic Differences in Adolescent Sexual and Reproductive Health: Marriage.," Health, Nutrition and Population Global Practice,World Bank Group, 2015. [Online]. Available: http://hdl.handle.net/10986/22589

[17] Fitriani, Health Promotion, 1st ed. Yogyakarta: Graha Ilmu, 2011. Yogyakarta: Graha Ilmu, 2011.

[18] S. Notoatmodjo, Health Promotion and Health Behavior (2012 revised edition). Jakarta: Rineka Cipta, 2012.

[19] Wawan A. and Dewi M., Developmental Psychology An Approach Throughout the Life Span. Yogyakarta: Nuha Medika, 2011.

[20] S. Notoatmodjo, Health promotion, theory and application. Jakarta: Rineka Cipta, 2005.

[21] M. Triyanti, L. Widagdo, and Syamsulhuda BM, "Increasing the Knowledge and Skills of Cadre of Child Development Monitoring at Posyandu using BBM and Mind Maping (MM)," Indones. Heal. Promot. J., vol. 12, no. 2, pp. 267-277, 2017, doi: 10.14710/jpki.12.2.265-277.

[22] Maulana H, Health Promotion. Jakarta: EGC, 2009.

[23] P. Hapitria and R. Padmawati, "The Effectiveness of Health Education through Multimedia and Face-to-Face Towards Knowledge and Attitudes of Pregnant Women About Breastfeeding and Breastfeeding," J. Care, vol. 5, no. 2, pp. 156-167, 2017.

[24] T. Nugroho, Maternity, Pediatric, Surgery and Internal Medicine Nursing Care. Yogyakarta: Nuha Medika, 2011.

[25] Arsyad A., Learning media. Jakarta: Rajawali Press, 2011. Jakarta: Rajawali Press, 2011.

[26] S. Notoatmodjo, Health Promotion Theory and Its Application. Jakarta: Rineka Cipta, 2007.

[27] A. Saifuddin, Research Methods. Yogyakarta: Student Library, 2013.

[28] Schiavo R., "Health communication: From theory to practice," John Wiley and Sons, 2013

[29] N. H. Hasan, "Perceptions of National Middle School Malay Language Teachers on the Implementation of KBAT in Teaching and Learning," Undergraduate Thesis. Faculty of Education, Universiti Kebangsaan Malaysia, 2016.

[30] S. M. Abdullah, "Social Cognitive Theory: A Bandura Thought Review published in 1982-2012," Psikodimensia, vol. 18, no. 1, pp. 85-100, 2019, doi: DOI 10.24167/psidim.v18i1.1708.

[31] S. Notoatmodjo, Health Promotion, Theory \& Application, ed. revision. Jakarta: Rineka Cipta, 2010.

[32] M. Jung, M. Arya, and K. Viswanath, "Effect of Media Use on HIV/AIDS-Related Knowledge and Condom Use in Sub-Saharan Africa: A Cross-Sectional Study," PLoS One, vol. 8, no. 7, pp. 1-9, 2013, doi: 10.1371/journal.pone.0068359.

[33] F. Nursalam, Efendi, Nursing Research Methods. Jakarta: Salemba Medika, 2012.

[34] M. S. Husaini and R. Panghiyangani, "The Influence of HIV/AIDS Counseling on Knowledge and Attitudes About HIV/AIDS Students of the Banjarbaru Midwifery Academy 2016," Bull. Heal. Res., vol. 45, no. 1, pp. 11-16, 2017, doi: 10.22435/bpk.v45i1.5787.11-16.

[35] Sumiyati, P. Hastuti, and A. Widiastuti, "The Effectiveness of Health Education on Knowledge and Attitudes of Toddlers About Pulmonary TB in Children in Banyumas Regency," LINK J., vol. 14, no. 1, 2018, doi: 10.31983/link.v14i1.2934. 